\title{
DAMPAK MOLASE TERHADAP PENINGKATAN KUALITAS BENIH BANDENG (Chanos chanos Forskal) PRODUK HATCHERY SKALA RUMAH TANGGA DI BALI UTARA
}

\section{THE IMPACT OF MOLASE TO INCREASED QUALITY OF MILKFISH Chanos chanos Forskal SEED PRODUCTION IN SMALL SCALE HATCHERIES AT NORT BALI}

\author{
Titiek Aslianti* dan Afifah Nasukha \\ Balai Besar Riset Budidaya Laut dan Penyuluhan Perikanan, BRSDM KP-KKP, Bali, 81155 \\ *E-mail: tiaspriyono@yahoo.com
}

\begin{abstract}
An unstable quality of milkfish seed (Chanos chanos) produced by small scale hatcheries at North Bali, leads to a decrease in aquaculture production. To anticipate, improving management for the seed production process had been conducted. The research was carried out in five hatcheries units, using three outdoor concrete tanks $(6 \mathrm{m3})$. Each tank was filled with a density of 100,000 eggs. The research was repeated in three cycles. Larvae were reared by the rearing standard procedures. Before rearing, the eggs were disinfected using $50 \mathrm{ppm}$ of iodine for 20 minutes. The rearing water was added with 2 ppm of molasses as a stimulant, started on D2 (2 days after hatching) until harvested on D16-18. The results showed that the range of survival rate of larvae on each hatchery was 82.57$92.04 \%$ with total lengths of 11.96-13.56 mm. Each tank produced milkfish seeds from 68,444 79,444 pcs. These results were improved, which produced only 35,750 - 42,900 pcs/tank, low survival rate $61.54-63.57 \%$, with the total length varied from 10 to $11.8 \mathrm{~mm}$, and the bone condition was still fully cartilage. Growth rate, survival rate, seed performance and condition of the vertebrae resulted from this research showed that molasse can be used to improve larval rearing media in small scale hatcheries and may produce high-quality milkfish seed, resulting in the rise in aquaculture production.
\end{abstract}

Keyword: milkfish, molasse, seeds, small scale hatcheries, quality

\begin{abstract}
ABSTRAK
Tidak stabilnya kualitas benih ikan bandeng produk Hatchery Skala Rumah Tangga (HSRT) di Bali Utara berdampak langsung terhadap produksi budidaya yang terus menurun. Mengantisipasi hal tersebut telah dilakukan perbaikan manajemen dalam proses produksi benih. Penelitian ini dilakukan di lima unit HSRT masing-masing menggunakan 3 unit bak beton berkapasitas $6 \mathrm{~m}^{3}$ yang berada di luar ruangan (outdoor). Setiap bak diisi telur bandeng dengan kepadatan 100.000 butir/bak. Penelitian diulang sebanyak 3 siklus, dengan metode pemeliharaan larva berdasar pada SOP dan CPIB Desinfeksi telur menggunakan iodin $50 \mathrm{ppm}$ selama 20 menit. Tetes tebu (molase) sebanyak $2 \mathrm{ppm}$, ditambahkan ke-dalam media pemeliharaan larva sebagai stimulan dan diberikan mulai hari ke-dua (D-2) sampai menjelang panen (D16-D18). Pemberian pakan alami dan pakan buatan disesuaikan dengan perkembangan umur larva. Hasil penelitian menunjukkan bahwa kelangsungan hidup benih di HSRT berkisar 82,57-92,04\% dengan kisaran panjang total benih setiap siklus 11,96-13,56 mm. Hasil panen setiap bak mencapai 68.444-79.444 ekor, jauh lebih baik daripada produksi sebelumnya yang berkisar 35.750-42.900 ekor/bak, dengan kelangsungan hidup 61,54-63,57\%, dan ukuran panjang total bervariasi $10-11,8 \mathrm{~mm}$ serta kondisi tulang belakang masih berbentuk tulang rawan. Berdasarkan pertumbuhan, kelangsungan hidup, performa morfologi benih dan kondisi tulang belakang, hasil penelitian ini menunjukkan bahwa penggunaan molase berdampak positif terhadap lingkungan pemeliharaan larva bandeng di HSRT dan mampu menghasilkan benih berkualitas baik sehingga dapat mendukung peningkatan produksi budidaya.
\end{abstract}

Kata kunci: bandeng, benih, HSRT, kualitas, molase 


\section{PENDAHULUAN}

Ikan bandeng (Chanos chanos, Forskal) sudah sejak lama dibudidayakan masyarakat dan umumnya dilakukan di tambak. Pangsa pasar ikan bandeng sangat luas (Cholik et al., 2005), selain untuk konsumsi domestik dan umpan tuna, juga telah menembus pasar luar negeri (Nurdjana dan Rakhmawati, 2006), bahkan termasuk satu diantara sepuluh komoditas unggulan ekspor Indonesia dari sektor perikanan (Cholik et al., 2006; Kordi, 2009). Sifat ikan bandeng yang adaptif terhadap fluktuasi salinitas dan toleran terhadap perubahan suhu, merupakan keunggulan tersendiri sehingga dapat dibudidayakan di perairan umum ataupun di Keramba Jaring Apung (KJA) laut (Pongsapan dan Tangko, 2005).

Dilaporkan bahwa produksi nasional bandeng dari tahun ketahun mengalami peningkatan yang pesat (Anonim, 2009). Seiring dengan upaya peningkatan produksi budidaya, tentunya akan diikuti dengan peningkatan permintaan benih yang berkualitas baik dan kontinyu. Keberadaan Hatchery Skala Rumah Tangga (HSRT) yang berperan sebagai sumber penghasil benih sangat memungkinkan dapat mendukung peningkatan produksi bandeng karena dapat memproduksi benih sepanjang tahun sehingga mampu mengatasi kesenjangan pasok benih alam yang bersifat musiman. Namun demikian pemenuhan permintaan benih sering kali hanya secara kuantititas, sedangkan secara kualitas kurang memenuhi standar jaminan mutu (quality assurance), bahkan cenderung menurun sehingga berdampak terhadap timbulnya permasalahan baru seperti yang dilaporkan petambak, bahwa benih tumbuh lambat/kerdil setelah dibudidayakan di tambak (Anonim, 2011). Mengamati menurunnya kualitas benih bandeng beberapa sumber melaporkan, bahwa kualitas benih banyak dipengaruhi oleh kualitas pakan yang diberikan selama periode pemeliharaan larva, juga dipengaruhi oleh kualitas telur yang berasal dari induk- induk yang dipelihara secara terkontrol namun dengan manajemen pemberian jenis pakan yang bervariasi (Astuti et al., 2012). Semakin menurunnya kualitas benih dapat mengakibatkan menurunnya produksi budidaya yang pada gilirannya akan berdampak langsung terhadap ekonomi masyarakat pembudidaya (Anonim, 2011).

Mengantisipasi hal tersebut upaya perbaikan kualitas benih telah dilakukan melalui berbagai penelitian diantaranya adalah perbaikan kualitas telur melalui perbandingan seks ratio induk bandeng (Priyono et al., 1997), perbaikan nutrisi pakan alami dalam pemeliharaan larva (Afifah dan Aslianti, 2010), perbaikan kualitas lingkungan pemeliharaan dengan memanfaatkan probiotik komersial (Aslianti et al., 2010 ; Musthofa et al., 2010), dan perbaikan teknik produksi benih secara menyeluruh yaitu mulai dari penanganan telur, pemanfaatan molase dalam media pemeliharaan larva, dan mengoptimalkan penggunaan rotifer sebagai pakan eksogen alami serta penentuan waktu panen berdasarkan pengamatan morfologi. Dari penelitian tersebut dihasilkan benih berkualitas baik dengan kisaran panjang total 12-14 mm, gerak renang aktif dan responsif, perkembangan tulang belakang kokoh dan panen dilakukan minimal pada umur 16 hari (Aslianti et al., 2011).

Dengan demikian HSRT mampu berperan sebagai sentra produksi benih bandeng berkualitas baik khususnya di Bali Utara, dan sekaligus dapat memperbaiki citra buruk tentang rendahnya kualitas benih produk HSRT di lingkungan petani tambak.

\section{METODE PENELITIAN}

\subsection{Pemilihan Lokasi HSRT}

HSRT yang digunakan untuk penelitian berlokasi di pantai Bali Utara, tepatnya di wilayah kecamatan Gerokgak, Kab. Buleleng, Prov. Bali dan ditentukan berdasarkan jarak antara satu HSRT dengan yang lainnya berkisar $10-15 \mathrm{~km}$. Lima unit 
HSRT yang terpilih terdiri dari HSRT di Desa Banyupoh, Desa Penyabangan, Desa Musi, Desa Sanggalangit, dan Desa Gerokgak. Masing-masing HSRT dikelola oleh kelompok ataupun dimiliki secara perorangan (Tabel 1, Gambar 1).

HSRT tersebut harus memiliki sarana/prasarana siap pakai antara lain bak beton berkapasitas $6 \mathrm{~m}^{3}$, tidak bocor, cat pada dinding bagian dalam bak tidak mengelupas, lengkap dengan pemipaan termasuk aliran listrik dan blower sebagai sumber aerasi serta penyiapan gen-set sebagai cadangan sumber listrik. Selain itu kontinyuitas kultur pakan alami fitoplankton (Nannochloropsis atau chlorella) harus terjamin dan berada terpisah dari bak kultur zooplankton rotifer (Brachionus rotundiformis), hal ini untuk menghindari terjadinya kontaminasi. Demikian juga penyediaan air laut maupun air tawar harus selalu tersedia kontinyu dan lancar. Saluran pembuangan air diupayakan tidak menggenang di sekitar bak pemeliharaan, sehingga lingkungan operasional hatchery tertata rapi dan hiegienis (Priyono et al., 2007).

\subsection{Pelaksanaan Penelitian}

Pelaksanan penelitian diawali dengan kegiatan di hatchery bandeng Balai Besar Riset Budidaya Laut dan Penyuluhan Perikanan (BBRBLPP) yang memelihara induk-induk bandeng secara terkontrol, dan berstatus sebagai penyedia telur yang baik (fertilitas \pm 80\%) (Priyono et al., 1997).

Tabel 1. Status dan pengelola HSRT di pantai Bali Utara yang digunakan untuk penelitian.

\begin{tabular}{lll}
\hline \multicolumn{1}{c}{ HSRT } & \multicolumn{1}{c}{ Status } & Nama Pengelola \\
\hline 1. Desa Banyupoh (BP) & Perorangan & Made Suarsana \\
2. Desa Penyabangan (PNYB) & Kelompok & Kelp. Laut Indah \\
3. Desa Musi (MS) & Perorangan & Putu Mangku \\
4. Desa Sanggalangit (SL) & Kelompok & Kelp. Niki Mina \\
5. Desa Gerokgak (GRK) & Perorangan & Suwono \\
\hline
\end{tabular}
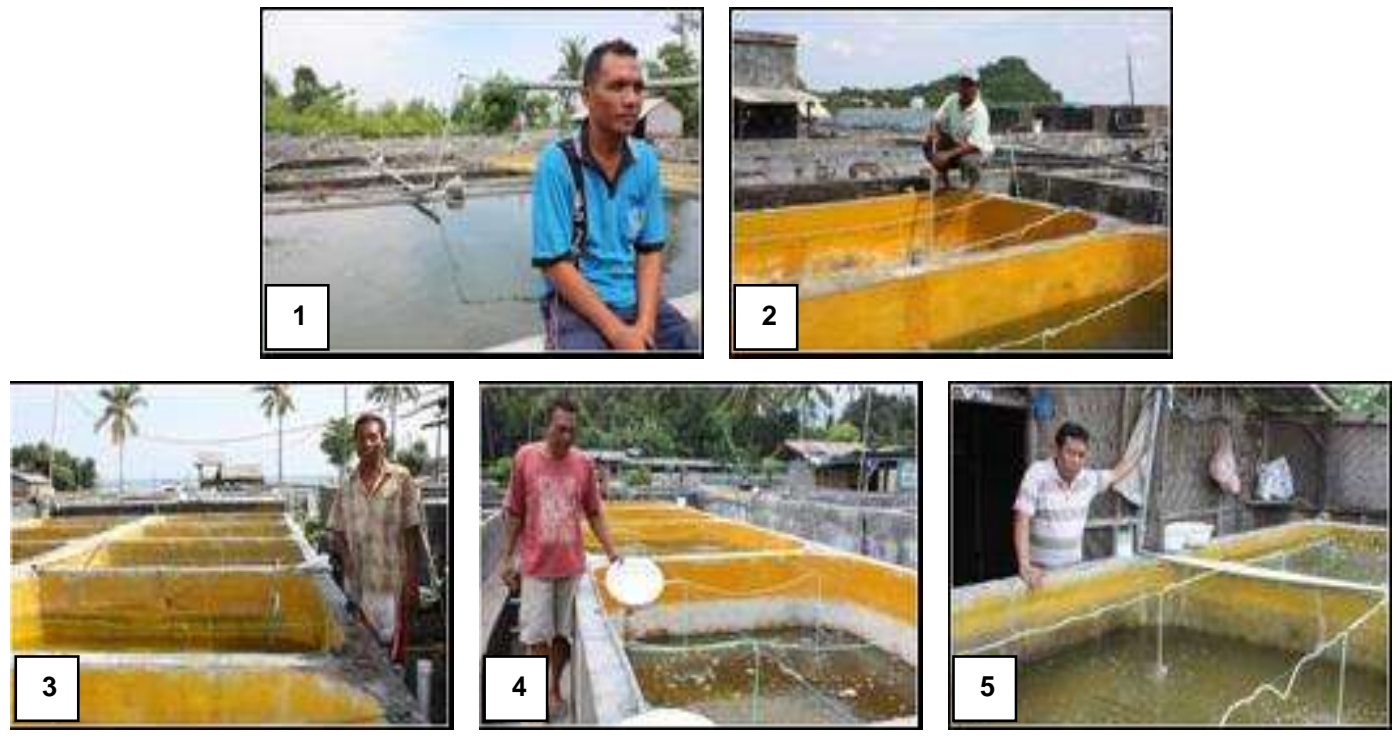

Gambar 1. 1.HSRT Desa Banyupoh; 2. HSRT Desa Penyabangan; 3. HSRT Desa Musi; 4. HSRT Desa Sanggalangit dan 5. HSRT Desa Gerokgak. Semua HSRT termasuk dalam wilayah Kec. Gerokgak, Kab. Buleleng. 
Telur-telur yang tertampung pada egg colector segera dipindah ke dalam bak penampungan telur (bak fiber volume 500 liter). Telur diaerasi (pengudaraan), selama 5-10 menit kemudian didiamkan sesaat hingga terlihat tingkatan pembuahan telur. Telur yang dibuahi terlihat berwarna bening transparan, melayang dan terapung, sedangkan telur yang tidak dibuahi berwarna putih keruh, mengendap di dasar wadah, dan segera dibuang dengan menggunakan alat sifon. Telur yang dibuahi didesinfeksi/ disucihamakan dengan cara perendaman menggunakan iodin 50 ppm selama 20 menit (Afifah et al., 2011). Permukaan dinding telur terlihat bersih tidak terinfeksi oleh parasit (Gambar 2). Selanjutnya telur dibilas dengan air laut bersih dan didistribusikan ke masing-masing HSRT sebanyak 3 kantong (100.000 butir/kantong) setiap siklus penebaran.
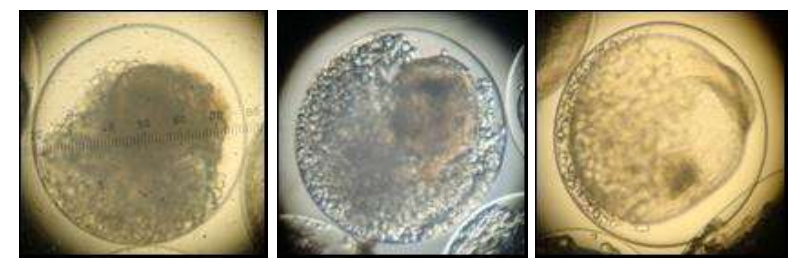

Gambar 2. Telur bandeng (diameter $1,2 \pm 0,05 \mathrm{~mm}$ ) setelah didesinfeksi.

\subsection{Pemeliharaan Larva}

Setiap HSRT menggunakan 3 unit bak beton yang dinding bagian dalamnya dicat warna kuning (light chrome yellow) dan berada di luar ruangan (outdoor). Bak diisi air laut (30-34 ppt) melalui saringan filterbag hingga volume $\pm 4 \mathrm{~m}^{3}$. Pipa aerasi diatur sedemikian rupa sehingga merata pada setiap bagian bak. Selanjutnya telur ditebar kedalam bak pemeliharaan larva yang telah disiapkan di masing-masing HSRT. Dalam waktu 20-24 jam pada suhu $28-30{ }^{\circ} \mathrm{C}$ telurtelur tersebut akan menetas dan dihitung daya tetasnya (Priyono et al., 2007). Tetes tebu sebagai stimulan sebanyak 2 ppm (Nasukha dan Aslianti, 2012) ditambahkan pada media pemeliharaan larva setiap hari sampai menjelang panen. Penelitian dilakukan sebanyak 3 siklus (16-18 hari/siklus) dengan metode pemeliharaan larva berdasar pada Standar Operasional Prosedur (SOP) dan Cara Pemeliharaan Ikan Yang Baik (CPIB) (Anonim, 2012).

Selama pemeliharaan larva, jumlah pakan alami (rotifer) dan pakan buatan/pellet (berupa butiran berukuran 2-4 $\mu$ ), masingmasing diberikan pada waktu yang disesuaikan dengan umur dan perkembangan morfologi larva. Hal ini berdasar pada kesesuaian ukuran bukaan mulut dan kesiapan organ cerna larva pada setiap tahapan pertambahan umurnya.

\subsection{Pengamatan dan Panen Benih}

Selama proses produksi benih, dilakukan pengamatan secara berkala pada setiap HSRT untuk melihat kecukupan ketersediaan pakan alami (rotifer dan Nannochloropsis), perkembangan morfologi larva (sirip dan mata), dan performa benih (keseragaman ukuran, aktifitas gerak renang, dan respons terhadap pakan serta hentakan,). Pengamatan laboratoris dilakukan terhadap sampel hasil panen untuk mengetahui pertumbuhan panjang total, bobot tubuh, dan perkembangan tulang belakang. Parameter tersebut masing-masing dilakukan dengan menggunakan alat mistar berketelitian $1 \mathrm{~mm}$ dan timbangan digital Ohaus Model SPJ2001; S/N 7130090657, Ohaus Corporation, Pine Brook, NJ USA, berketelitian $0,1 \quad$ gram. Sedangkan perkembangan tulang belakang yang dianalisis dengan metode pewarnaan ganda menurut Potthoff (1984), diamati dengan menggunakan mikroskop-komputer merk Nikon SMZ 1000, yang dilengkapi dengan lensa type Plan Apo 1X WD-70, dan layar monitor berukuran 20 inci. Pengamatan terhadap objek hewan uji dilakukan secara diskriptif, dan didokumentasikan dengan menggunakan kamera digital merek Sony Cyber-shot 7.2 mega pixels. Pengamatan kualitas air dilakukan seminggu sekali, terdiri 
dari parameter suhu, salinitas, dan kandungan oksigen terlarut (dissolved oxygen).

Kelangsungan hidup benih setiap siklus dihitung pada akhir pemeliharaan pada kisaran umur 16-18 hari. Panen dilakukan setelah terlihat performa morfologi benih layak untuk dipanen. Tulang belakang larva saat panen harus kokoh dan berada pada fase transisi dari tulang rawan (cartilage) menjadi tulang keras (bone).

\subsection{Analisis Data}

Semua data yang diperoleh dihimpun dalam bentuk tabulasi dan dianalisis secara diskriptif serta dihitung menggunakan program Microsoft Excel 2011.

\section{HASIL DAN PEMBAHASAN}

Hasil pengamatan terhadap rata-rata daya tetas, kelangsungan hidup, jumlah benih hasil panen setiap siklus dan setiap bak (ekor), dari masing-masing HSRT, tertera pada Tabel 2. Pengamatan panjang total benih hasil panen pada siklus 1, 2, 3, dan rata-ratanya tertera pada Tabel 3.

Tabel 2 diketahui bahwa rata-rata daya tetas telur dari kelima HSRT sebesar $79,89 \pm 6,40 \%$. Berdasarkan pengamatan dengan menggunakan mikroskop, terlihat bahwa tingkat pembuahan (fertilitas) telur dan proses pembelahan selnya mulai dari fase morula, blastula, gastrula dan embrio berlangsung sempurna selama 20-24 jam Dikatakan oleh Priyono et al., (2007), jika persentase daya tetas telur tinggi, dan larvanya dipelihara pada media yang cukup nutrisi, dapat diprediksi bahwa larva akan tumbuh normal sehingga mendukung kelangsungan hidup benih yang cenderung tinggi.

Tabel 2. Rata-rata daya tetas, kelangsungan hidup, jumlah benih hasil panen total, setiap siklus dan setiap bak (ekor) dari masing-masing HSRT.

\begin{tabular}{lccccc}
\hline $\begin{array}{c}\text { Hatchery } \\
\text { Desa }\end{array}$ & $\begin{array}{c}\text { Daya tetas } \\
(\%)\end{array}$ & $\begin{array}{c}\text { Kelangsung } \\
\text { an hidup(\%) }\end{array}$ & $\begin{array}{c}\text { Jml benih } \\
\text { total (ekor) }\end{array}$ & $\begin{array}{c}\text { Jml benih } \\
\text { /siklus (ekor) }\end{array}$ & $\begin{array}{c}\text { Jml benih/bak } \\
\text { (ekor) }\end{array}$ \\
\hline 1. Banyupoh & 79,39 & 92,04 & 646.250 & 215.417 & 71.806 \\
2. Penyabangan & 69,43 & 82,57 & 616.000 & 205.333 & 68.444 \\
3. Musi & 85,11 & 89,14 & $\left.715.000^{*}\right)$ & $\left.238.333^{*}\right)$ & $79.444 *)$ \\
4. Sanggalangit & 85,06 & 87,34 & 660.000 & 220.000 & 73.333 \\
5. Gerokgak & 80,48 & 87,22 & 621.115 & 207.038 & 69.013 \\
Rata-rata \pm SD & $79,89 \pm$ & $87,66 \pm$ & $651673 \pm 39$. & $217.224 \pm 13.2$ & $72.408 \pm$ \\
& 6,40 & 5,56 & 735 & 45 & 4.415 \\
\hline
\end{tabular}

*) Jumlah benih tertinggi

Tabel 3. Panjang total $(\mathrm{mm})$ benih hasil panen siklus-1, 2, 3 dan rata-ratanya dari masingmasing HSRT.

\begin{tabular}{lcccc}
\hline \multirow{2}{*}{ Hatchery Desa } & \multicolumn{4}{c}{ Panjang Total (mm) } \\
& Siklus-1 & Siklus-2 & Siklus-3 & Rata-rata \\
\hline 1. Banyupoh & 11,60 & 12,99 & 13,85 & 12,81 \\
2. Penyabangan & 12,00 & 13,96 & 13,62 & 13,19 \\
3. Musi & 12,35 & 12,86 & 13,05 & 12,75 \\
4. Sanggalangit & 13,22 & 13,31 & 13,94 & 13,49 \\
5. Gerokgak & 11,06 & 13,58 & 13,36 & 12,67 \\
Rata-rata \pm SD & $11,96 \pm 0,81$ & $13,34 \pm 0,45$ & $13,56 \pm 0,36$ & $12,95 \pm 0,35$ \\
\hline
\end{tabular}


Kondisi ini terlihat dari tingkat kelangsungan hidup benih yang dihasilkan masing-masing HSRT berkisar 82,57-92,04\% dengan rata-rata sebesar $87,66 \pm 5,56 \%$. Hal ini menunjukkan bahwa penggunaan tetes tebu dalam media pemeliharaan larva bandeng mempunyai dampak positif terhadap kesuburan media sehingga mampu menutrisi larva guna mendukung pertumbuhannya dan meningkatkan kelangsungan hidup benih menjadi lebih tinggi dari pada tahun-tahun sebelumnya yang hanya berkisar 61,5463,57\% (Anonim, 2011).

Benih bandeng yang dihasilkan masing-masing HSRT mempunyai performa yang proporsional yakni panjang total berkisar 11,96-13,56 $\mathrm{mm}$ dengan rata-rata sebesar 12,95 $\pm 0,35 \mathrm{~mm}$ (Tabel 3). Gambar 3, juga dijelaskan bahwa pada siklus pertama, panjang total benih teredah $(11,06 \mathrm{~mm})$ dicapai HSRT Gerokgak, dan tertinggi $(13,22$ $\mathrm{mm})$ dicapai HSRT Sanggalangit. Namun pada siklus kedua $(12,86-13,96 \mathrm{~mm})$ dan ketiga $(13,05-13,94 \mathrm{~mm})$, panjang total benih masing-masing HSRT terlihat sudah lebih merata, sesuai ukuran standar benih bandeng yang memenuhi jasminan mutu di dalam dan di luar negeri (Anonim, 2012). Performa benih yang dihasilkan tampak seragam dengan gerak renang yang gesit, aktif dan responsif.

Ditinjau dari persentase jumlah benih hasil panen berdasarkan ukuran panjang total pada siklus 1, 2 dan 3, pada masing-masing HSRT menunjukkan bahwa pada siklus pertama (Gambar 4), hanya 2 HSRT (Musi dan Sanggalangit) yang benihnya berukuran seragam $(>11 \mathrm{~mm})$, sedangkan HSRT yang lain benihnya tidak seragam. Namun hasil panen benih pada siklus ke-dua dan ke-tiga (Gambar 5 dan 6), terlihat bahwa tingkat keseragaman benih pada semua HSRT mencapai $100 \%$ dengan panjang total $>12$ $\mathrm{mm}$.

Ditinjau dari persentase jumlah benih hasil panen berdasarkan ukuran panjang total pada siklus 1, 2 dan 3, pada masing-masing HSRT menunjukkan bahwa pada siklus pertama (Gambar 4), hanya 2 HSRT (Musi dan Sanggalangit) yang benihnya berukuran seragam $(>11 \mathrm{~mm})$, sedangkan HSRT yang lain benihnya tidak seragam. Namun hasil panen benih pada siklus ke-dua dan ke-tiga (Gambar 5 dan 6), terlihat bahwa tingkat keseragaman benih pada semua HSRT mencapai $100 \%$ dengan panjang total $>12$ $\mathrm{mm}$.

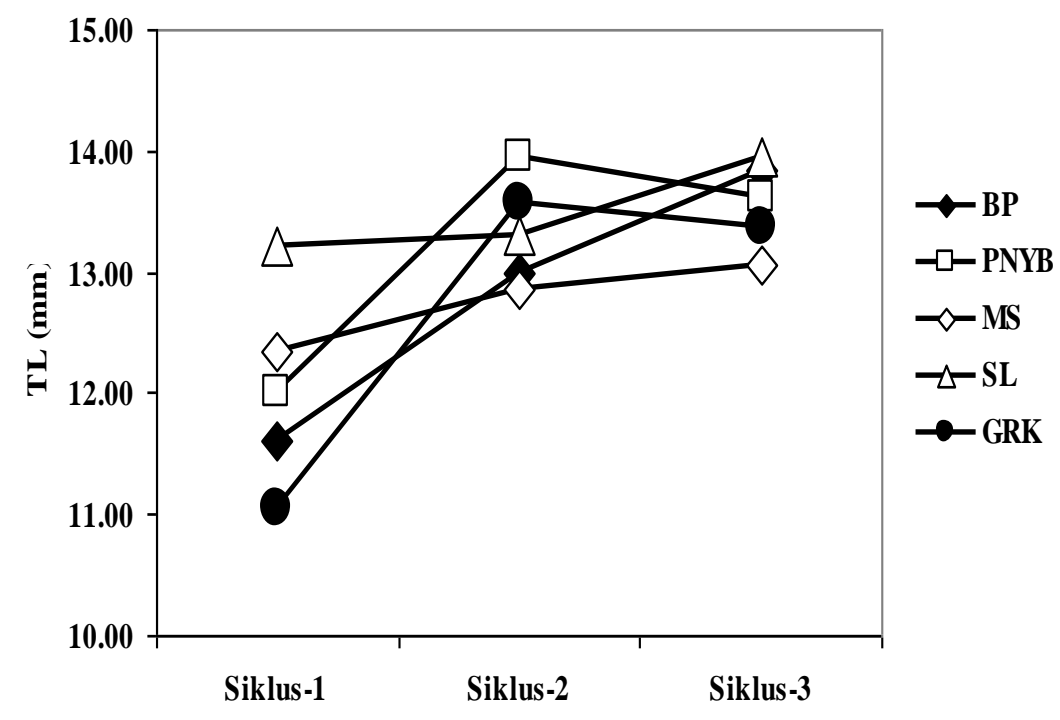

Gambar 3. Rata-rata pertumbuhan panjang total benih ikan bandeng hasil panen pada siklus 1, 2 dan 3 dari masing-masing HSRT. 


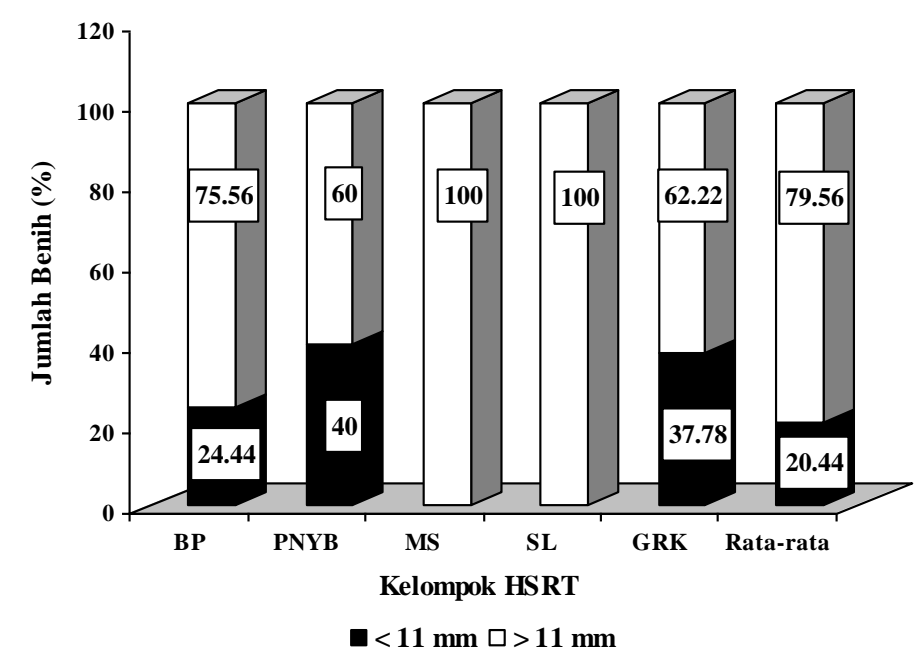

Gambar 4. Persentase jumlah benih hasil panen siklus pertama pada masing-masing HSRT ber-dasarkan ukuran panjang total (mm).

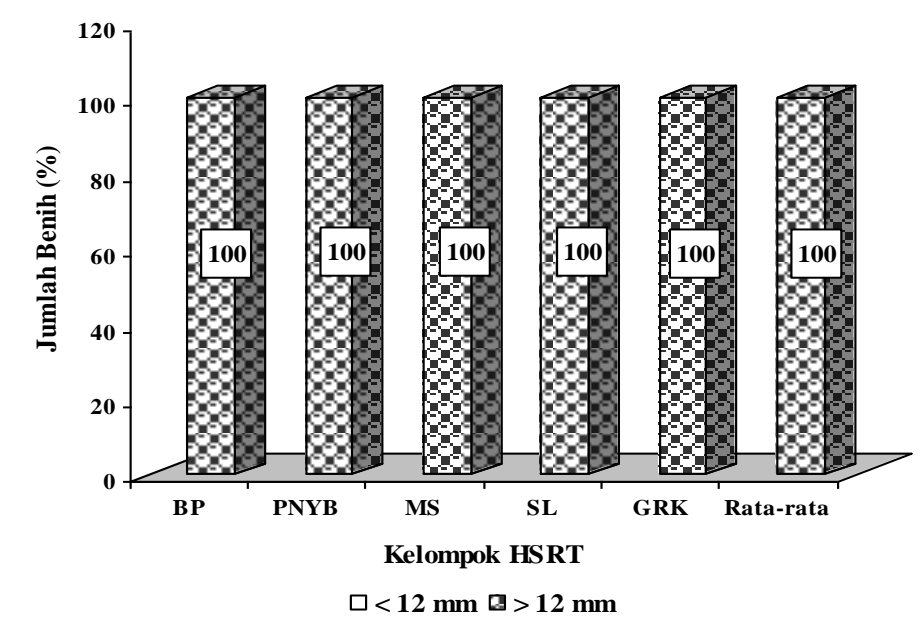

Gambar 5. Persentase jumlah benih hasil panen siklus ke-dua pada masing-masing HSRT ber-dasarkan ukuran panjang total $(\mathrm{mm})$.

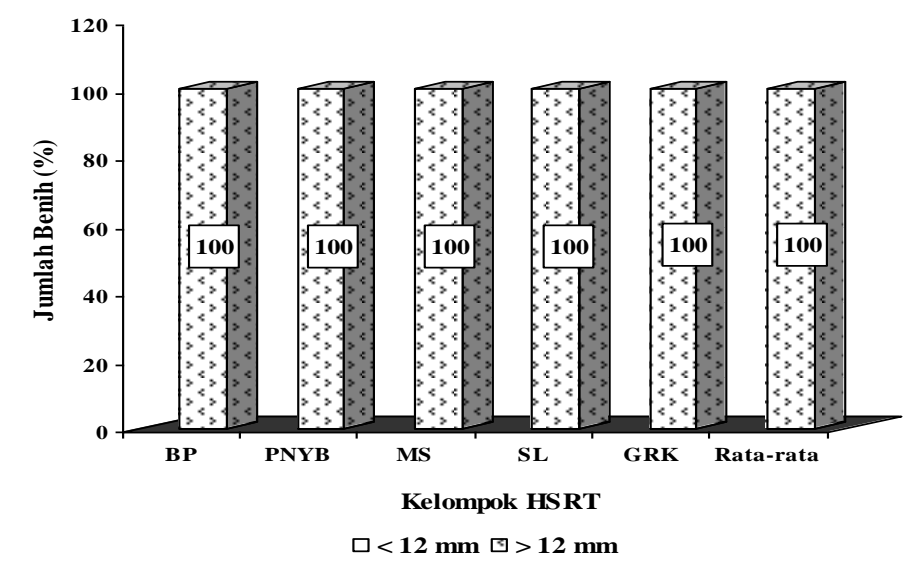

Gambar 6. Persentase jumlah benih hasil panen siklus ke-tiga pada masing-masing HSRT ber-dasarkan ukuran panjang total $(\mathrm{mm})$ 
Ditinjau dari jumlah total produksi hasil panen masing-masing HSRT (3 siklus) (Tabel 2; Gambar 7), menunjukkan bahwa HSRT desa Musi mempunyai nilai paling tinggi (715.000 ekor), sedangkan HSRT lainnya hanya mencapai total produksi 616.000-660.000 ekor, namun rata-rata produksi benih setiap bak pada setiap HSRT telah mencapai 72.408 ekor/bak Jika dibandingkan dengan jumlah produksi tahuntahun sebelumnya rata-rata hasil yang diperoleh jauh lebih rendah (39.325 ekor/bak) (Anonim, 2011), sedangkan hasil penelitian ini memperlihatkan adanya peningkatan yang konsisten sekitar dua kali lipat. Hal ini menunjukkan bahwa penggunaan tetes tebu pada setiap siklus produksi telah mampu memperbaiki lingkungan pemeliharaan larva bandeng sehingga meningkatkan produksi benih, baik secara kuantitas maupun kualitas.

Penggunaan tetes tebu dalam media pemeliharaan berfungsi memacu tumbuhnya mikroorganisme dan dapat dimanfaatkan oleh larva sebagai pakan alami, sehingga mendukung dalam setiap fase/tahapan pertumbuhannya. Pertumbuhan yang baik pada akhirnya dapat meningkatkan kelangsungan hidup larva hingga saat panen (Anonim, 2011).

Tetes tebu dilaporkan Suastuti (1998), mengandung $48-56 \%$ gula (molase) dan unsur-unsur mikro (trace element). Molase diketahui mengandung unsur karbon (37\%), sukrosa $(31 \%)$ dan beberapa asam amino serta mineral (32\%) yang berfungsi dapat me-ningkatkan kesuburan perairan (Avnimelech, 1999). Selanjutnya dikatakan bahwa unsur karbon berperan penting dalam menjaga kesuburan dan menstabilkan kualitas air media pemeliharaan larva karena karbon merupakan unsur hara mikro penyusun senyawa-senyawa organik dan sebagai bahan utama dalam proses fotosintesis oleh fitoplankton perairan. Sedangkan unsur-unsur mikro seperti kobalt, boron, iodium, tembaga, mangan, dan seng, kesemuanya diketahui sangat penting bagi kehidupan organisme.

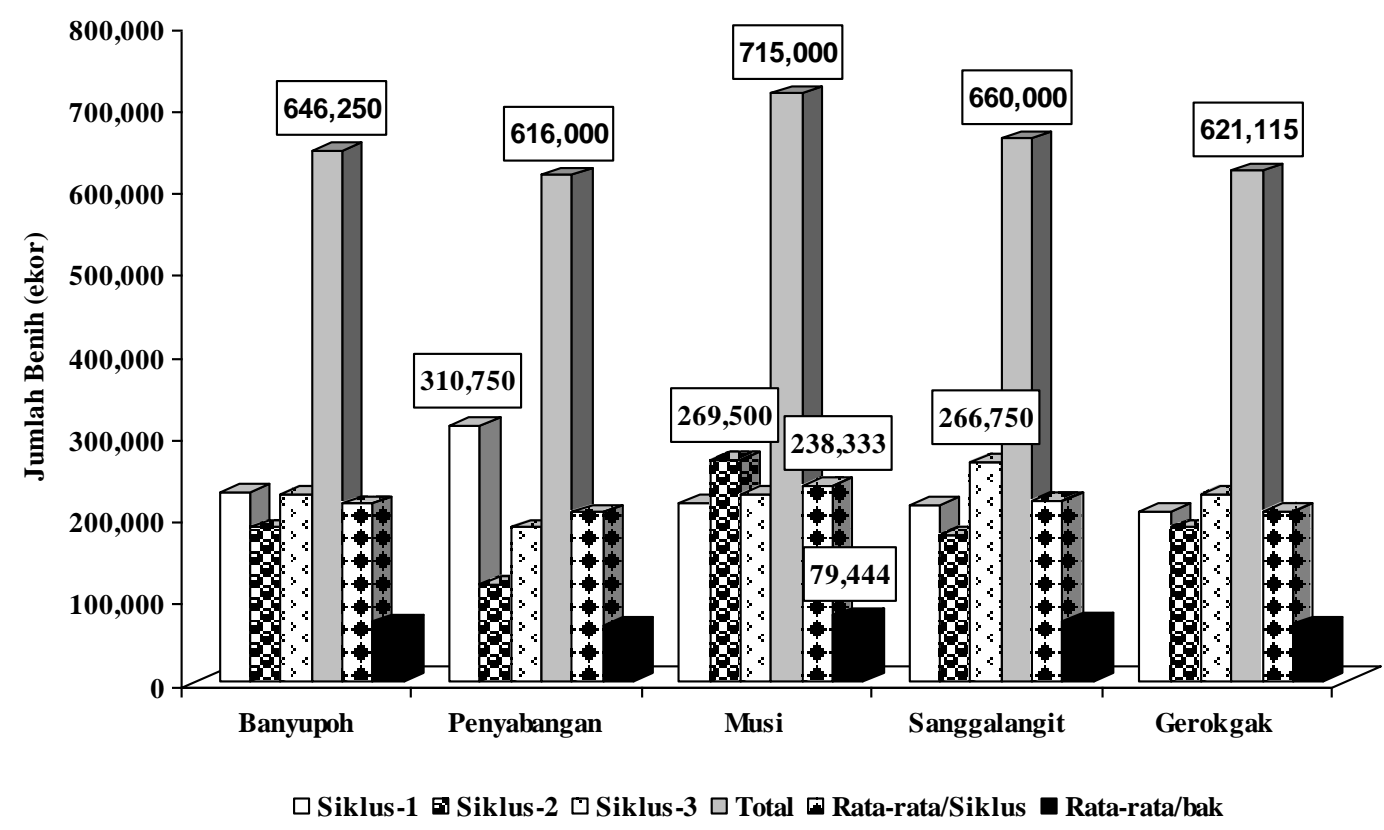

Gambar 7. Jumlah total produksi benih bandeng hasil panen setiap HSRT (3 siklus). 
Ditinjau dari hasil pengamatan terhadap tulang belakang benih saat panen, terlihat bahwa hampir 90\% tulang belakang benih telah berubah dari tulang rawan (cartilage) menjadi tulang keras (bone) yang berwarna kemerahan (Gambar 9). Performa benih juga menunjukkan gerak renang yang lebih gesit dan aktif mengitari dinding bak. Ini dapat dijadikan sebagai tolok ukur dan dasar pertimbangan dalam kegiatan transportasi benih ke berbagai daerah produksi bandeng.

Pengamatan kualitas air seperti suhu, salinitas, dan DO yang dilakukan seminggu sekali selama 3 siklus produksi pada semua HSRT relatif stabil (Tabel 4), sehingga mendukung pertumbuhan larva dan berdampak positif terhadap kelangsungan hidup benih sampai masa panen.

Tabel 4. Kisaran nilai kualitas air (suhu, salinitas dan DO) hasil pemantauan pada siklus 1,2 dan 3 di semua HSRT yang dilakukan seminggu sekali.

\begin{tabular}{lcccc}
\hline \multicolumn{1}{c}{ Parameter } & Siklus-1 & Siklus-2 & Siklus-3 & Kisaran Nilai (Hasil Pustaka) \\
\hline Suhu air $\left({ }^{\circ} \mathrm{C}\right)$ & $27,7-29,2$ & $27,4-29,0$ & $27,0-30,4$ & $28-31$ (Tebbutt, 1992) \\
Salinitas $(\mathrm{ppt})$ & $30,0-38,0$ & $32,0-41,0$ & $30,0-39,0$ & $28-35$ (Anonim, 2012) \\
DO $(\mathrm{mg} / \mathrm{L})$ & $3,8-5,8$ & $3,4-5,5$ & $3,0-5,2$ & $>5 \mathrm{ppm}$ (Anonim, 2012) \\
\hline
\end{tabular}
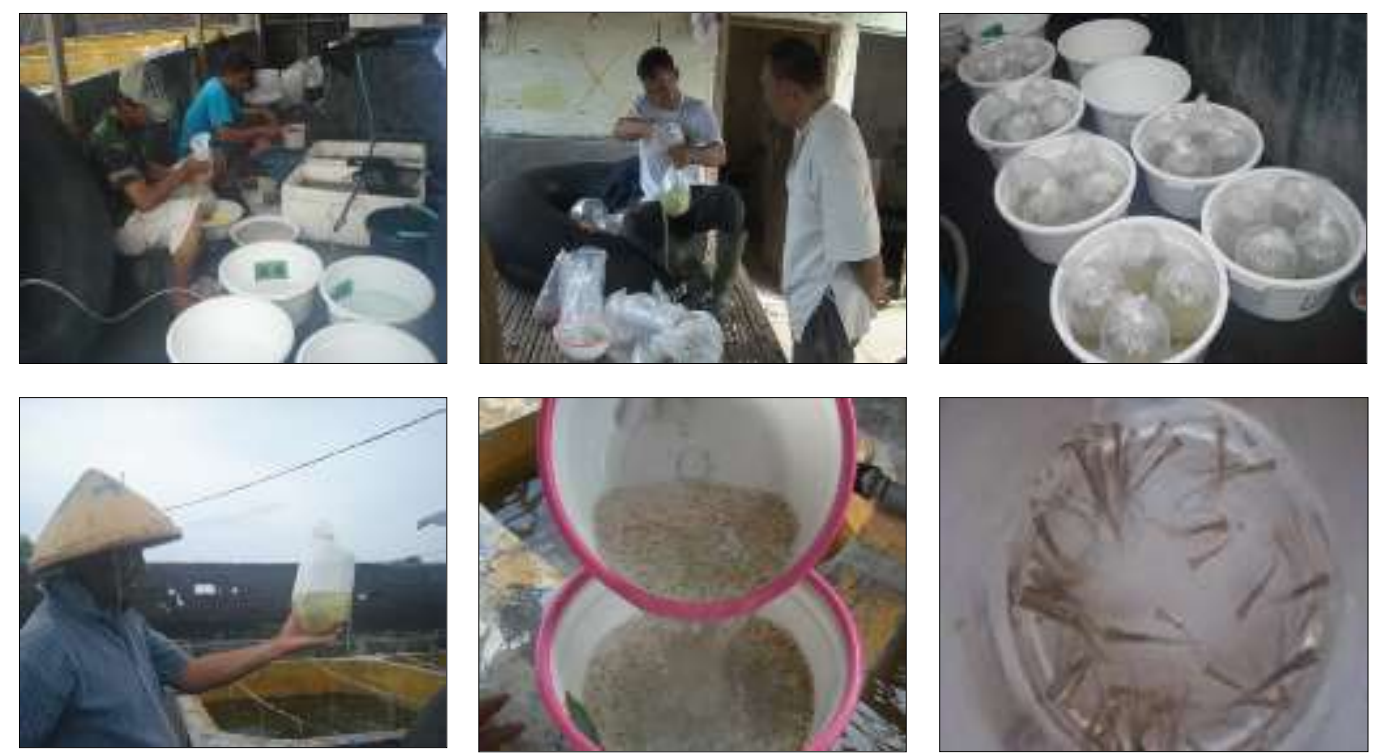

Gambar 8. Aktivitas panen, pengepakan dan performa benih bandeng hasil panen di HSRT.
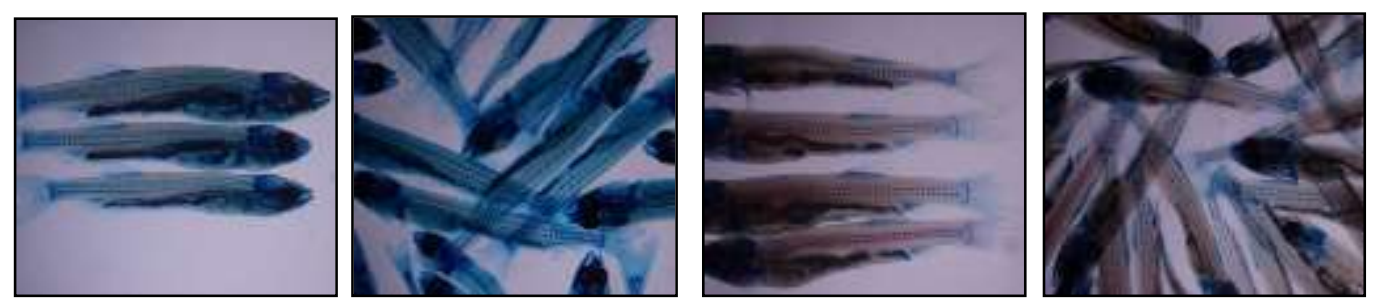

Gambar 9. Kondisi tulang belakang benih bandeng hasil panen HSRT pada umur 16-18 hari, sudah berbentuk tulang keras (bone) dan berwarna kemerahan. 


\section{KESIMPULAN}

Dari penelitian ini dapat disimpulkan bahwa penggunaan molase dalam media pemeliharaan larva bandeng di HSRT dapat meningkatkan kelangsungan hidup benih mencapai 82,57-92,04\% dengan kisaran panjang total $11,96-13,56 \mathrm{~mm}$ dan sesuai standar jamiman mutu (quality assurance). Jumlah total produksi tertinggi dicapai HSRT desa Musi sebesar 715.000 ekor atau sebesar 79.444 ekor per bak. Kondisi tulang belakang benih sudah berbentuk tulang keras (bone) mempunyai performa morfologi proporsional dengan gerak renang yang aktif dan responsif sehingga dapat dijadikan tolok ukur dalam persyaratan transportasi benih.

\section{UCAPAN TERIMA KASIH}

Penelitian ini dilakukan dengan meng-gunakan dana DIPA Penelitian BBRBLPP-KKP tahun 2014. Terima kasih kepada para pengelola HSRT yang telah memfasilitasi dan bersedia mendukung pelaksanaan penelitian ini sehingga diperoleh teknologi yang tepat guna dan berhasil guna bagi masyarakat terkait. Penghargaan yang tinggi kami sampaikan pada para teknisi litkayasa yang telah membantu dan berpartisipasi aktif dalam kegiatan pengambilan sampel (sampling), menghimpun data dan analisis laboratorium hingga laporan penelitian ini dapat selesai tepat waktu.

\section{DAFTAR PUSTAKA}

Afifah dan T. Aslianti. 2010. Peranan vitamin B12 dan kalsium sebagai pengkaya rotifer terhadap kualitas larva bandeng. Prosiding Seminar Nasional Perikanan Indonesia 2010. Sekolah Tinggi Perikanan, Jakarta, 23 Desember 2010. Hlm.: 1-5.

Afifah, T. Aslianti, dan S.Z. Musthofa. 2011. Penggunaan iodine sebagai desinfektan pada telur bandeng
(Chanos chanos Forsskal). Prosiding Seminar Nasional Tahunan VIII Hasil Penelitian Perikanan dan Kelautan. Jurusan Perikanan Fakultas Pertanian UGM. HIm.PL-19:1-4.

Anonim. 2009. Rencana Strategis Perikanan Budidaya 2005-2009. Direktorat Jenderal Budidaya. Departemen Kelautan dan Perikanan. $96 \mathrm{hlm}$.

Anonim. 2011. Ketika Kualitas Bandeng Merosot. Trobos. Edisi 145 Tahun XIII Oktober 2011. Hlm.: 83-55.

Anonim. 2012. Pedoman Pembenihan skala kecil ikan air payau dan laut. Direktorat Perbenihan. Diretorat Jenderal Perikanan Budidaya. Kementerian Kelautan dan Perikanan. Hlm.: 166-197.

Avnimelech,Y. 1999. Carbon nitrogen ratio as a control element in Aquaculture system. Aquaculture, 176: 227-235.

Aslianti, T., Afifah dan S.Z. Musthofa. 2010. Dosis efektif probiotik dalam pemeliharaan larva bandeng, Chanos chanos secara terkontrol. Prosiding Seminar Nasional Perikanan Indonesia 2010. Sekolah Tinggi Perikanan, Jakarta, 2-3 Desember 2010. Hlm.: 273-278.

Aslianti, T., Afifah dan A.A.K. Alit. 2011. Pengamatan performansi tulang belakang benih ikan bandeng produksi Hatchery Skala Rumah Tangga (HSRT) sebagai indikator kualitas benih. Prosiding Seminar Nasional Kelautan VII. Universitas Hang Tuah. Surabaya, 20 April 2011. Hlm.:BI.105-111.

Astuti, N.W.W., M. Marzuqi, dan R. Andamari. 2012. Penggunaan bahan pengkaya pada pakan induk bandeng untuk menunjang produksi telur. Prosiding Indoaqua-Forum Inovasi Teknologi Akuakultur. Pusat Penelitian dan Pengembangan Perikanan Budidaya. Badan Penelitian dan Pengembangan 
Kelautan dan Perikanan. Hlm.: 455460.

Cholik, F., A.G. Jagatraya, R.P. Poernomo, dan A. Jauzi. 2005. Akuakultur Tumpuan Harapan Masa Depan Bangsa. Kerja sama antara Masyarakat Perikanan Nusantara (MPN) dengan Taman Akuarium Air Tawar (TAAT) Taman Mini Indonesia Indah. Penerbit PT. Victoria Kreasi Mandiri. Hlm.: 184189.

Cholik, F., S. Moeslim, E.S. Heruwati, T. Ahmad dan A. Jauzi. 2006. Sebelas Lompatan Perikanan Budidaya Indonesia. 60 Tahun Perikanan Indonesia. Masyarakat Perikanan Nusantara, 2006. Hlm.: 201-212.

Kordi, G. M. 2009. Sukses Memproduksi Bandeng Super Untuk Umpan, Ekspor dan Indukan. Penerbit Andi. Jakarta. 145 hlm.

Musthofa, S.Z., Afifah, T. Aslianti dan A. Priyono. 2010. Pengaruh penambahan probiotik komersial terhadap pertumbuhan dan kelangsungan hidup larva bandeng, Chanos chanos Forsskal. Kumpulan Makalah Seminar Nasional Biodiversitas III. Departemen Biologi. Fakultas Sains dan Teknologi, Universitas Airlangga. Hlm.: 96-99.

Nasukha, A., dan T. Aslianti. 2012. Alternatif Penggunaan Tetes Tebu dalam Media Pemeliharaan Larva Bandeng (Chanos chanos Forsskal). Prosiding Seminar Nasional Tahunan IX. Hasil Penelitian Perikanan dan Kelautan Th. 2012, Jilid I. Budidaya Perikanan. Univ. Gadjah Mada, Jogyakarta, 14 Juli 2012. Hlm.: PN$09: 1-7$

Nurdjana, M.L. dan D. Rakhmawati. 2006. Membangun Kejayaan Perikanan Budidaya. 60 Tahun Perikanan Indonesia. Masyarakat Perikanan Nusantara, 2006. Hlm.: 189-200.
Pongsapan, D.S. dan A.M. Tangko. 2005. Ikan bandeng potensial dibudidayakan dalam keramba jaring apung (KJA) di laut. Warta Penelitian Perikanan Indonesia. Edisi Akuakultur, 11(1): 12-15.

Potthoff, T. 1984. Clearing and Staining Techniques in Ontogeny and Systematic of Fishes (ed. by. H. g. moser et al.). Special Publication I, American Society of Ichtyologist and Herpetologists: 35-37.

Priyono, A., T. Setiadharma, G. Sumiarsa dan K. Sugama. 1997. Pengaruh perbandingan jenis kelamin (seks rasio) induk bandeng terhadap kualitas dan kuantitas telur. Prosiding Simposium Perikanan Indonesia II, Ujung Pandang, 2-3 Desember 1997. Hlm.: 209-213.

Priyono, A., T. Aslianti, T. Setiadharma, K. Suwirya, and F.J. Rafael. 2007. Hatchery Management of Milkfish, Chanos chanos Forskal in Indonesia. Research Institute for Mariculture Gondol-Bali. Center for Aquaculture Research and Developmen. Ministry of Marine Affairs and Fisheries. $2007.36 \mathrm{p}$

Rachmansyah, Usman dan T. Ahmad. 2001. Produksi bandeng super dalam keramba jaring apung di laut. Warta Penelitian Perikanan Indonesia. Edisi khusus, 7(1): 18-27.

Suastuti, N.G.A.M.A. 1998. Pemanfaatan hasil samping industri pertanian molase dan limbah cair tahu sebagai sumber karbon dan nitrogen untuk produksi biosurfektan oleh Bacillus $s p$. Galur komersial lokal. Program Pasca Sarjana IPB. Bogor. $36 \mathrm{hlm}$.

Tebbutt, T.H.Y. 1992. Principles of water quality control. Fourth edition. Pergamon Press, Oxford. 251 p.

Received : 28 June 2019

Reviewed : 27 August 2019

Accepted : 12 Dessember 2019 
